\title{
Review of the nutrition situation in the Eastern Mediterranean Region
}

\author{
Lara Nasreddine ${ }^{1}$, Jennifer J. Ayoub ${ }^{1}$ and Ayoub Al Jawaldeh ${ }^{2}$
}

${ }^{1}$ Department of Nutrition and Food Science, Faculty of Agricultural and Food Sciences, American University of Beirut, Beirut, Lebanon. ${ }^{2}$ WHO Regional Office for the Eastern Mediterranean, Cairo, Egypt (Correspondence to: A. Al Jawaldeh: aljawaldeha@who.int).

\begin{abstract}
This situation analysis for the World Health Organization Eastern Mediterranean Region focuses on specific nutrition indicators, namely low birth weight, exclusive breastfeeding, under- and overnutrition (anthropometric indicators) and anaemia. The regional average prevalence of low birth weight and exclusive breastfeeding was estimated at $19.31 \%$ and $29.3 \%$, respectively. Stunting, wasting and underweight had an average prevalence of $28 \%, 8.69 \%$ and $18 \%$, respectively. Afghanistan, Djibouti, Pakistan, Sudan and Yemen had the highest burden of stunting (> 30\%). Prevalence of anaemia ranged from $7.4 \%$ to $88 \%$ in children aged < 5 years and from $19.9 \%$ to $63 \%$ in women of childbearing age. Of concern is the increasing trend in overweight and obesity among adults and children. Average prevalence of overweight and obesity was $27 \%$ and $24 \%$ in adults and $16.5 \%$ and $4.8 \%$ in school-aged children, respectively. The highest levels of obesity were reported from Bahrain, Kuwait, Qatar and the United Arab Emirates. This review highlights the double burden of malnutrition in countries of the Region and calls for the prioritization of policies aimed at improving the population's nutritional status.
\end{abstract}

Keywords: Breastfeeding; malnutrition; anaemia; obesity; stunting

Citation: Nasreddine L, Ayoub JJ, Al Jawaldeh A. Review of the nutrition situation in the Eastern Mediterranean Region. East Mediterr Health J. 2018;24(1):77-91. https://doi.org/10.26719/2018.24.1.77

Received: 18/07/17; accepted: 4/01/18

Copyright (C) World Health Organization (WHO) 2018. Some rights reserved. This work is available under the CC BY-NC-SA 3.0 IGO license (https:// creativecommons.org/licenses/by-nc-sa/3.o/igo).

\section{Introduction}

Malnutrition represents the number one risk factor in the global burden of disease (1). Despite increasing attention to the alleviation of hunger worldwide (1), undernutrition remains a devastating multifaceted problem affecting infants, young children, adolescent girls and women (2). Children who suffer from chronic undernutrition in the early stages of life fail to grow and develop to their full potential, both mentally and physically (3), and are at increased risk for noncommunicable diseases (NCDs) (4). Acute undernutrition, indicated by wasting in children aged $<5$ years, is a strong predictor of mortality (5). Conversely, overnutrition and obesity-associated morbidity are plaguing the global economies and health systems $(6,7)$. In November 2014, the Rome Declaration on Nutrition, issued at the Second International Conference on Nutrition, acknowledged that malnutrition in all its forms affects people's health and well-being and presents a threat to the social and economic development of communities and countries (8). The Declaration also acknowledged that different forms of malnutrition coexist within most countries. This is particularly true for countries of the World Health Organization (WHO) Eastern Mediterranean Region, which typically suffer from a double burden of malnutrition. The Regional Strategy on Nutrition 2010-2019 indicated that the burden of disease associated with inadequate nutrition continues to grow (9). While the prevalence of undernutrition remains high in some Eastern Mediterranean countries, the burden of overweight, obesity and diet-related chronic diseases is increasing at an alarming rate. Factors that may play a role in modulating malnutrition include maternal health and nutrition, early life feeding practices, dietary intake and the food environment (10-13).

Overcoming malnutrition in all of its forms caloric undernourishment and obesity - necessitates a combination of evidence-based interventions in various areas, to guarantee the availability of and access to healthy diets $(14,15)$. These interventions should be guided by a thorough analysis of the nutrition situation and accurate data on nutritional indicators in the Region. These data are crucial, not only for the development of appropriate policies and interventions, but also for measuring progress. It is in this context that we have undertaken this review of nutritional indicators in the Region, including low birth weight (LBW), exclusive breastfeeding (EB), anaemia, and under- and overnutrition based on anthropometric indicators, among children aged $<5$ years, school-age children and adults. This paper also examines secular trends in per capita energy and macronutrient supply in the Region, which includes 22 countries (16).

\section{Methodology}

For this narrative review, data pertinent to the six WHO core nutrition indicators were reviewed, including: (1) prevalence of EB (defined as no other food or drink, not even water, except breast milk for the first 6 months of life) (17); (2) LBW (defined as the percentage of infants 
weighing < $2.5 \mathrm{~kg}$ at birth) (18); (3) stunting (height-for-age z score <-2) (19); (4) wasting (weight-for-height z score < -2) (19); (5) obesity/overweight (weight-for-height z score $>2$ ) (19) in children aged < 5 years; and (6) anaemia in pregnant women (haemoglobin < $11 \mathrm{~g} / \mathrm{dl}$ ) (20) and women of childbearing age (haemoglobin $<12 \mathrm{~g} / \mathrm{dl}$ ). Data related to overweight and obesity in school-aged children [body mass index (BMI)-for-age $\mathrm{z}$ score $>1$ (21) and adults (BMI $\left.\geq 25 \mathrm{~kg} / \mathrm{m}^{2}(22)\right]$ were also abstracted. In addition, per capita dietary supply data (energy and macronutrients) were reviewed based on food availability data from the Food and Agriculture Organization of the United Nations (FAO) statistical database (23). The following electronic databases were searched between January 15 and April 20, 2015: MedLine, PubMed, Scopus, Google Scholar, WHO STEPS Country Reports (24), WHO Global Schoolbased Student Health Survey (25), WHO Global Database on Child Growth and Malnutrition (26), UNICEF Multiple Indicator Cluster Survey datasets (27). Food and Nutrition in Numbers (28) and FAO-UN FAOSTAT Food Balance Sheets (23). Websites of the ministries of health in the respective countries were also reviewed to identify additional data sources. The weighted regional average was calculated for each nutrition indicator, based on data available. When data were available at various time points, the annual rate of change was calculated for specific nutrition indicators.

\section{Results}

\section{Prevalence of LBW}

The weighted average prevalence of LBW in the Eastern Mediterranean Region was estimated at $19.31 \%$. LBW prevalence was $>30 \%$ in Sudan (28) and Pakistan (28) and reached $45 \%$ in Yemen (29) (Figure 1). The lowest rates of LBW were reported from Morocco (30), the United Arab Emirates (UAE), the Islamic Republic of Iran, Tunisia, Kuwait and Libya (28). Over time, an increasing trend in LBW prevalence was noticed in Yemen $(28,29)$, Pakistan (28), Lebanon (28), Oman (31,32), Somalia $(33,34)$ and the Syrian Arab Republic (28). The remaining countries have mostly witnessed a stabilization or a decrease in LBW rates. This decrease was particularly noticeable in the UAE (28), Morocco $(17,28)$ and Djibouti (28).

\section{Prevalence of EB}

The regional average for EB was estimated at $29.3 \%$, with the lowest rates being observed in Somalia (35), Tunisia (36), Yemen $(28,37)$, Kuwait (28), Oman (28), Lebanon $(28,38)$, Qatar (39,40), Iraq (41), Jordan (42) and Morocco (43) (Figure 2). The highest rates were reported from Afghanistan (44), the Islamic Republic of Iran (45) and Djibouti (46). The prevalence of EB decreased with infant age. In Egypt, for example, the prevalence of EB decreased from $45.7 \%$ among infants aged $0-4$ months to $30.3 \%$ among those aged 0-6 months (17,47). Similarly, a 2006 study

Figure 1 Prevalence of low birth weight in the Eastern Mediterranean Region

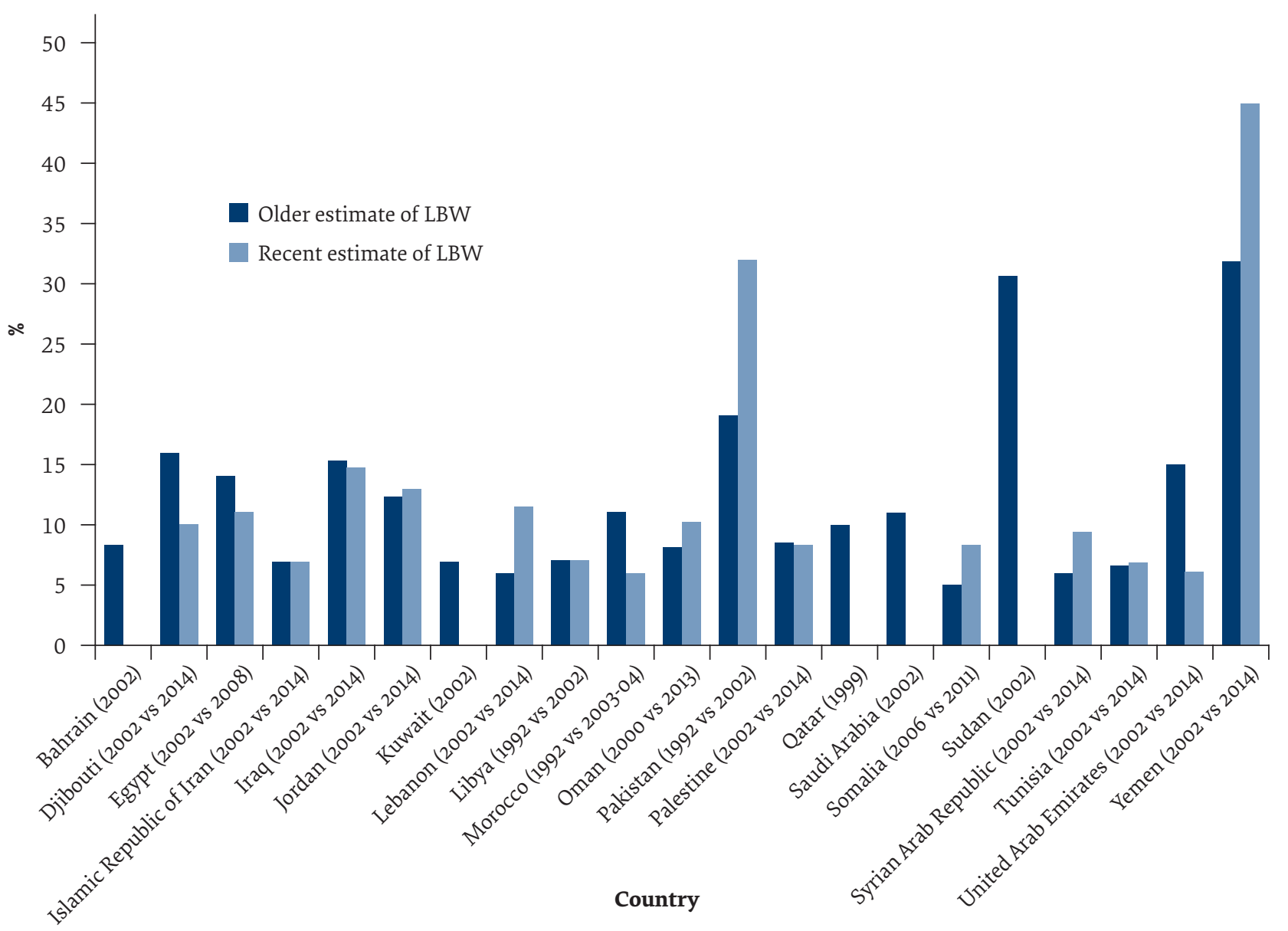


Figure 2 Prevalence of exclusive breastfeeding in the Eastern Mediterranean Region

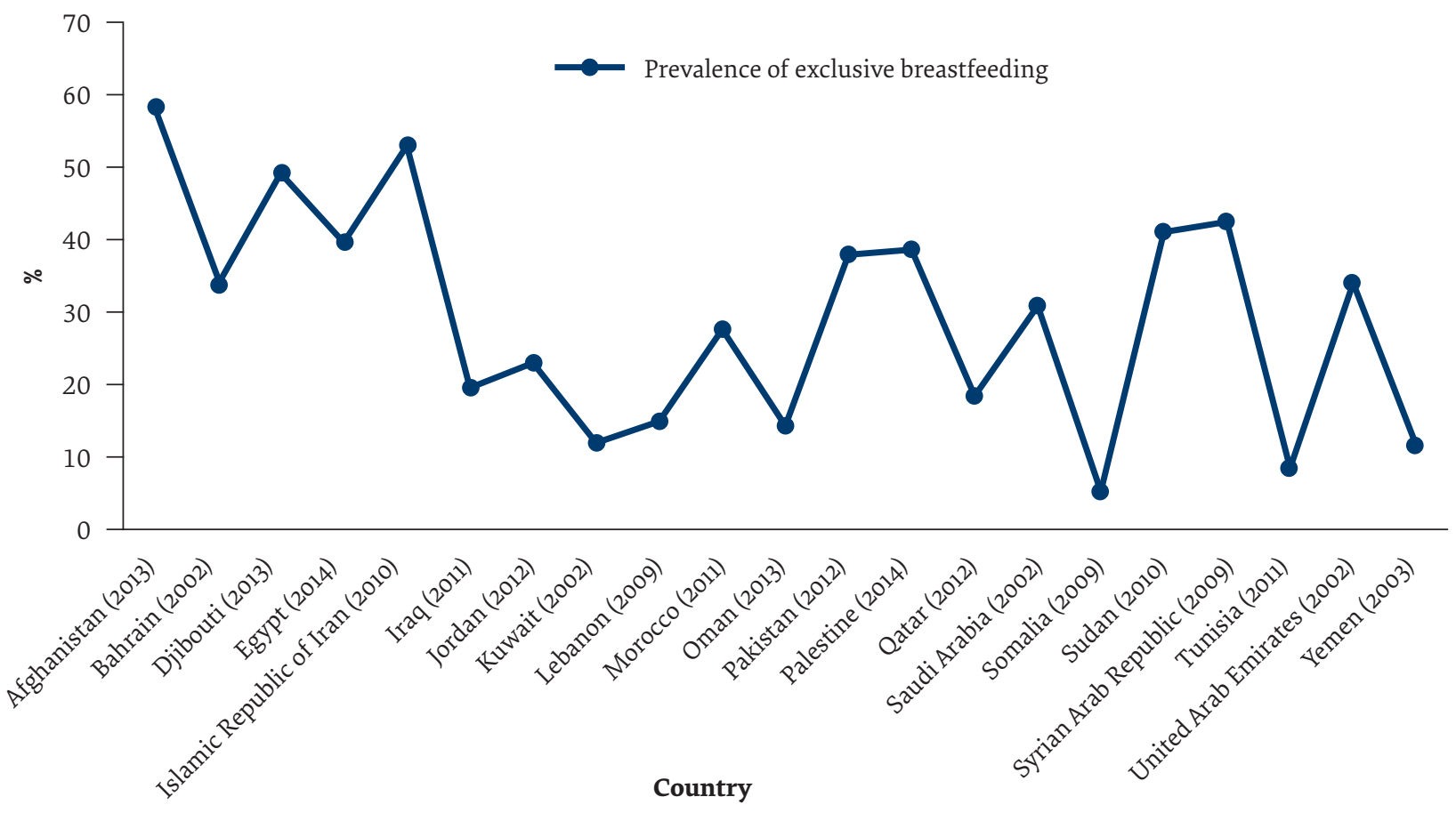

conducted in Lebanon (48) showed that the proportion of exclusively breastfed infants declined from $52.4 \%$ at age 1 month to $23.4 \%$ at 4 months and $10.1 \%$ at 6 months. Furthermore, a decreasing trend in the prevalence of EB has been noticed over time in some countries of the Region. This is particularly true for Morocco (51\% in 1992 and $27.8 \%$ in 2011 ) (43), Lebanon (26.6\% in 2000 and $14.8 \%$ in 2009)(17,28,38,49), Oman (31.3\% in 2005 and $14.4 \%$ in 2013), Sudan $(74.6 \%$ in $1992-1993$ and $41 \%$ in 2010$)(17,28,41,50,51)$, Somalia (21\% in 1999 and 5.3\% in 2009) $(17,35,41,52)$, Yemen (17.8\% in 1997 and $11.5 \%$ in 2003$)(28,37,53)$, and Jordan $(27 \%$ in 2002 and $23 \%$ in 2012$)(38,41-43,49,50)$. In contrast, an increasing trend was observed in the Islamic Republic of Iran (44\% in 2002 and 53.1\% in 2010) (41,45), Egypt (30.3\% in 2003 and $39.7 \%$ in 2014$)(17,47,54)$, Iraq $(12.4 \%$ in 2000 and $19.6 \%$ in 2011 ) (41,55), Pakistan (22.8\% in $1990-1991$ and $38 \%$ in 2012) (41,56) and occupied Palestinian territory $(26.6 \%$ in 2010 and $38.6 \%$ in 2014$)(57,58)$.

Prevalence of stunting, wasting and underweight in children aged $<5$ years

The estimated weighted regional averages for stunting, wasting and underweight were $28 \%, 8.69 \%$ and $18 \%$, respectively. The prevalence of wasting was highest in Djibouti (46), Sudan (51), Yemen (59) and Somalia $(60,61)$, while the prevalence of underweight was highest in Afghanistan (44) and Yemen (59) (Figure 3). Countries such as Iraq $(55,61-63)$, Libya $(61,64,65)$, Egypt $(54,66)$ and Sudan $(51,61,67)$, which are experiencing political unrest, have witnessed an increase in the prevalence of wasting over time. Similarly, an increasing trend in the prevalence of underweight was observed in Djibouti $(61,68,69)$, Sudan $(51,61,67)$, Iraq $(61-63)$, Libya $(61,64,65)$ and the Syrian Arab Republic $(61,70)^{1}$. The highest rates of stunting were noted in Yemen (59), Pakistan (61,71), Afghanistan (44), Sudan (51) and Djibouti (46), ranging between $29.7 \%$ and $46.5 \%$. The average annual rate of change in the prevalence of stunting in the Region was estimated at $-2.8 \%$. Of concern is the increasing prevalence of stunting that has been observed in Djibouti $(61,68,69,72)$ and Pakistan $(61,71,73,74)$.

\section{Prevalence of anaemia}

The prevalence of anaemia ranged from $7.4 \%$ to $88 \%$ in children aged $<5$ years (haemoglobin $<11 \mathrm{~g} / \mathrm{dl})(20), 7.4^{-}$ $40.9 \%$ in school-aged children (haemoglobin $<12 \mathrm{~g} / \mathrm{dl}$ ) (20), $16-81 \%$ in pregnant women, and $19.9-63 \%$ among women of reproductive age. The highest prevalence of anaemia was found in Sudan for children aged $<5$ years (88\%) (75) and pregnant women (81\%) (75), in Oman (40.9\%) for school-aged children (76) and in Djibouti (63\%) (77) for women of childbearing age.

\section{Prevalence of overweight and obesity}

\section{Adults}

The estimated weighted average prevalence of adult overweight and obesity in the Region was $27 \%$ and $24 \%$, respectively. A higher prevalence of obesity was noted among women compared to men $(78-83)^{2}$. The highest level of obesity was reported from Kuwait $(42.5 \%$ in

Syrian Ministry of Health and Central Bureau of Statistics. Rapid Nutrition Assessment (RNA). Final RNA report; 2014 (unpublished data).

2 Food and Nutrition Administration/Ministry of Health Kuwait. Kuwait National Surveillance System (KNSS). Annual report; 2013 (unpublished 
Figure 3 Prevalence of stunting, wasting and underweight among children aged $<5$ years in the Eastern Mediterranean Region

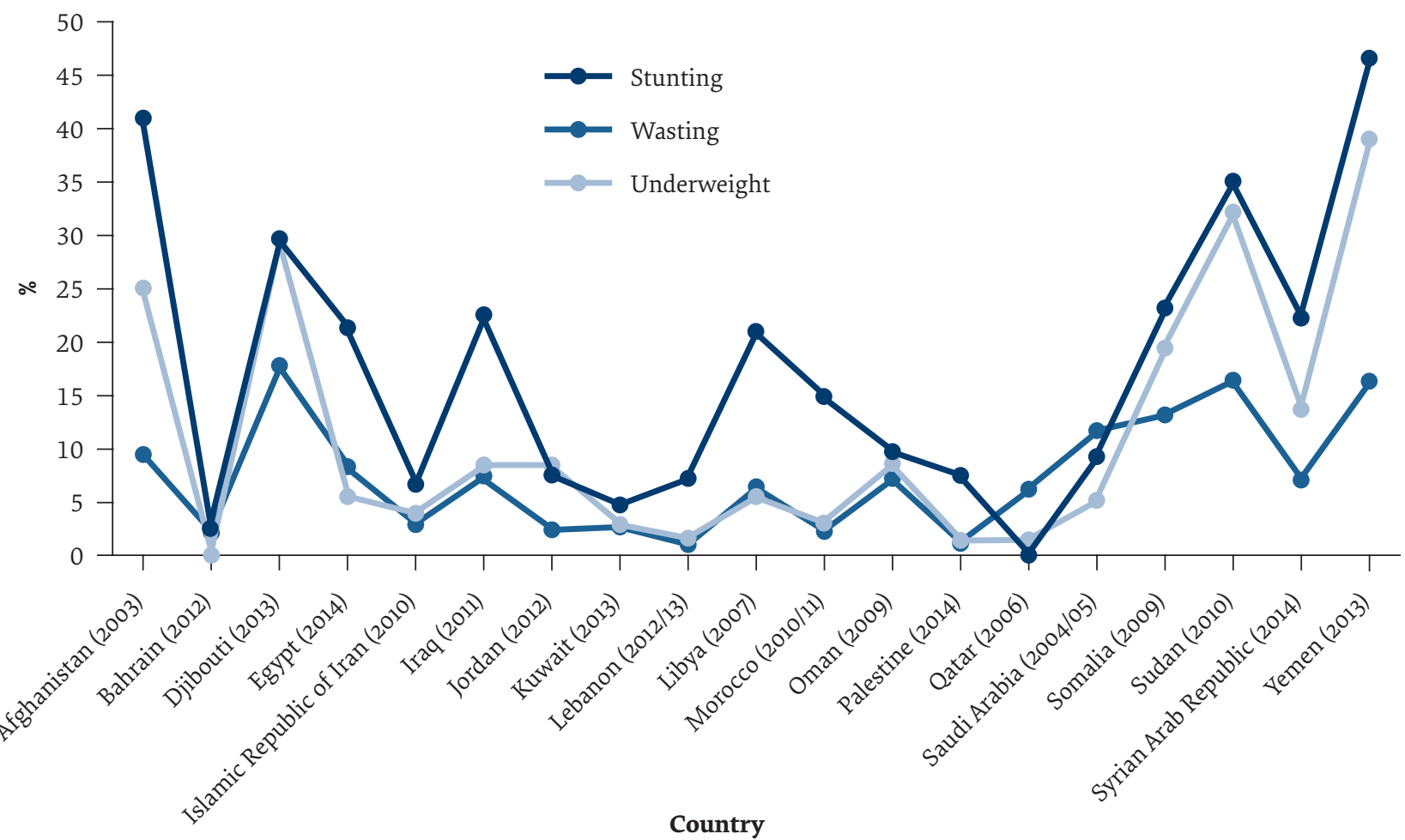

men and $47.1 \%$ in women $)^{2}$, Qatar $(39.5 \%$ in men and $43.2 \%$ in women) (83), Bahrain $(32.3 \%$ in men and $40.3 \%$ in women) (79), the UAE (33\%) (84), Egypt (31.3\%) (80) and Libya (30.5\%) (85). The prevalence of obesity was lowest in Somalia (6.7\% in women) (35), Afghanistan (8.3\% in women) (44) and Yemen (8.8\%) (86). Available data suggest an increasing secular trend in the prevalence of adult obesity in most countries of the Region. This trend was more pronounced in countries such as the UAE $(88,89)$, Tunisia (90,91), Afghanistan (44), Kuwait (92), Bahrain $(78,93)$ and Lebanon (93).

\section{Women of reproductive age}

Data on the prevalence of obesity in women of reproductive age (15-49 years) were available for Afghanistan (44), Egypt (66), Jordan (42), Libya (94) and Somalia (35) (Figure 4). Furthermore, in a study conducted in 2012 in the occupied Palestinian territory, the prevalence of obesity was estimated at $15.6 \%$ among mothers aged $18-28$ years, $35.8 \%$ among those aged $29-39$ years and $56.8 \%$ among those aged $40-50$ years (95).

\section{School-age children}

The estimated weighted average prevalence of overweight and obesity among school-age children (13-15 years) was $16.46 \%$ and $4.83 \%$, respectively. The highest prevalence of obesity was observed in Kuwait $(29.6 \%)^{3}$, Bahrain $(21.7 \%)^{4}$ and the UAE (14.4\%) (96), while the lowest rates were reported from Pakistan (1\%) (97), Morocco (2.5\%) (98), Afghanistan (2.7\% in girls) (44), Sudan (3.6\%) (99), Yemen (4.4\%) (100) and Djibouti (4.6\%) (101). Available data suggested an increase in the prevalence of overweight and obesity amongst school-age children. This was particularly true for the Islamic Republic of Iran (102, 103), Lebanon (93), Qatar (104, 105), Saudi Arabia (106-108), Tunisia $(109,110)$ and Bahrain $(111,112)$.

\section{Children aged < 5 years}

The estimated weighted average prevalence of overweight and obesity in children aged $<5$ years was $8.42 \%$. The highest prevalence was observed in Qatar (28.7\%) (113), Libya (22.4\%) (61,64), the Syrian Arab Republic (17.9\%) (61,114) and Egypt (14.9\%) (54), while the lowest was reported from Yemen (2\%) (59) and Sudan (2.9\%) (51). Available data suggest an increasing trend in the prevalence of overweight and obesity over time. This was particularly true for Afghanistan (44,61), Kuwait (61,115117), Libya $(61,64,65)$, Oman $(61,118,119)$, Pakistan $(61,73,118)$, Saudi Arabia (118) and Tunisia (36,61,120).

\section{Energy and macronutrient supply}

Food availability data (23) highlight a gradual secular increase in dietary energy supply (DES) in the Region between 1969-1971 and 2011, except for Afghanistan and Somalia, where DES decreased. The average increase in DES for the Region was $583.8 \mathrm{kcal} / \mathrm{day}$, with the highest

\footnotetext{
3 Food and Nutrition Administration/Ministry of Health Kuwait. Kuwait National Surveillance System (KNSS). 2013 Annual Report (unpublished data).

4 Gharib N, Rasheed P. National Nutrition Survey for School Children age 6-18 in Bahrain. Nutrition Section, Kingdom of Bahrain Ministry of Health (unpublished data).
} 
Figure 4 Prevalence of obesity $\left(\mathrm{BMI} \geq 30 \mathrm{~kg} / \mathrm{m}^{2}\right)$ in women of reproductive age (15-49 years) in some Eastern Mediterranean Region countries

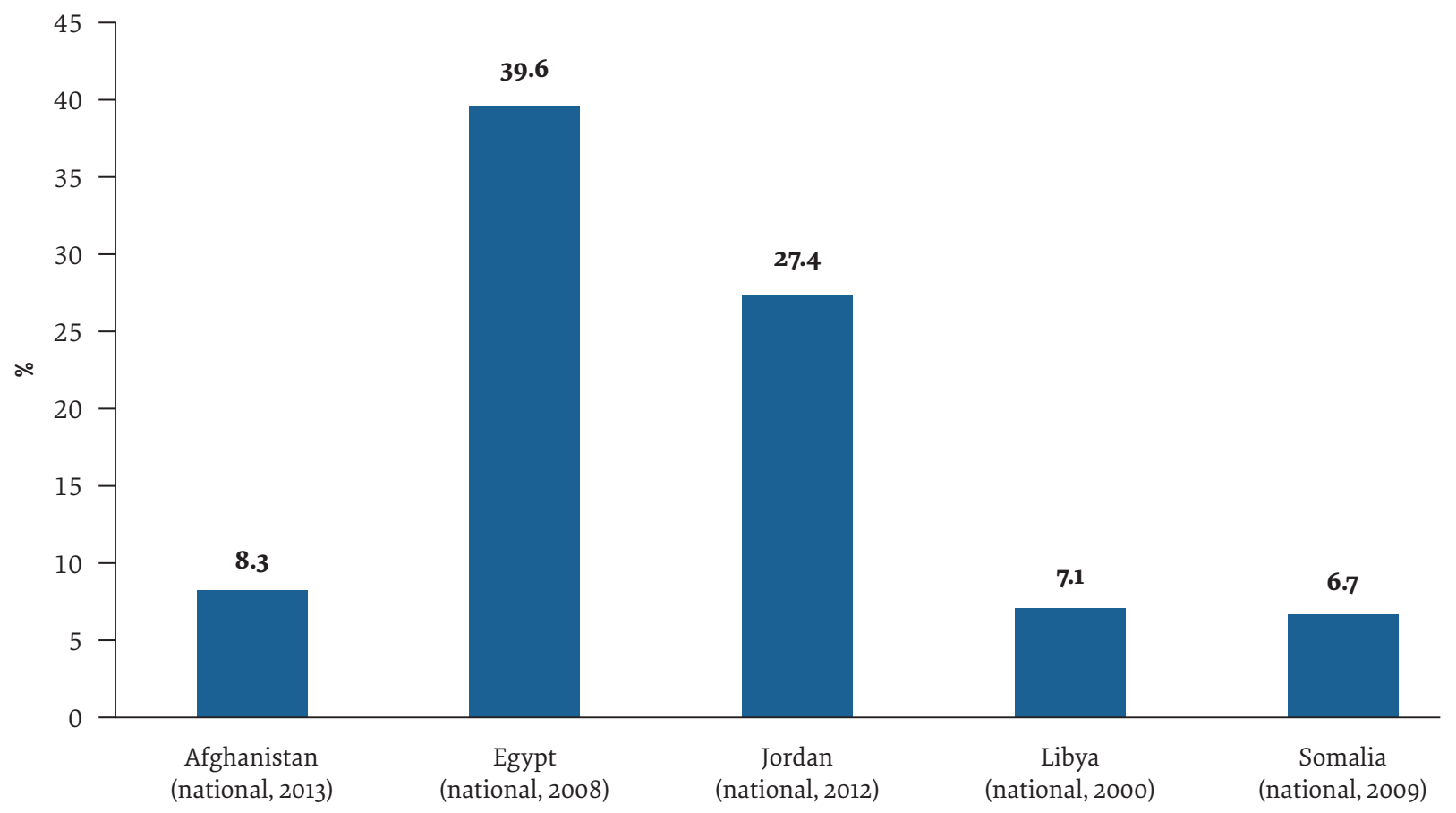

increases observed in Egypt (1290 kcal/day) and Saudi Arabia (1238 kcal/day), followed by the Islamic Republic of Iran (995 kcal/day), Tunisia (978 kcal/day), Morocco (962 kcal/day), Jordan (960 kcal/day), Libya (958 kcal/day) and Kuwait (926 kcal/day). The rise in DES was coupled with an increase in average dietary fat supply, which has increased from $51.8 \mathrm{~g} /$ day in 1969 to $77.7 \mathrm{~g}$ /day in 2011. During this period, fat supply has almost doubled in the Islamic Republic of Iran, Iraq, Jordan, Kuwait, Lebanon, the Syrian Arab Republic and Saudi Arabia. The data also showed that the contribution of dietary fat to DES has increased in most countries of the Region, with the average increase being estimated at $4 \%$ of DES between 1969-1971 and 2011. The highest increases were noted in Pakistan (13.05\%), Saudi Arabia (12.2\%), the Syrian Arab Republic (8.62\%), Jordan (8.04\%), the Islamic Republic of Iran $(6.12 \%)$, Kuwait $(5.86 \%)$ and Lebanon $(5.81 \%)$. Parallel to the increase in fat supply, a relative decrease in the contribution of carbohydrates to DES was noted in most countries, with an average of $4 \%$. In contrast, the contribution of protein to DES was found to be stable over the past 4 decades, except for Somalia, which has witnessed a $2 \%$ decrease.

\section{Discussion}

This review highlighted the double burden of malnutrition in the Eastern Mediterranean Region, with undernutrition coexisting with overnutrition in most countries. The regional prevalence of LBW $(19.31 \%)$ was higher than the global average of $16 \%$ (excluding China) (18) and higher than estimates reported from the United States of America (USA) and Europe $(8.1 \%$ and $7.1 \%$, respectively) (121). When examining the annual rates of change, only Djibouti $(-3.1 \%)$, Egypt $(-3.5 \%)$, Morocco $(-4.6 \%)$ and the UAE $(-4.9 \%)$ appeared to be on track towards meeting the global nutrition targets $(-2.74 \%$ for LBW) (122). This is of concern given that LBW children tend to have higher rates of subnormal growth, illnesses, neurodevelopmental problems and cognitive defects $(123,124)$. In the Region, LBW may be linked, in many instances, to poor maternal health and prenatal conditions, such as poverty, crowded home environments, unfavourable work conditions (125), infections, short interpregnancy intervals, maternal obesity, smoking and poorer nutrition including anaemia $(126,127)$, and rural residence (127).

This review also documents a low regional average of EB (29.3\%), indicating poor adherence to the WHO's infant feeding recommendations. Of more concern is the observed decreasing trend in EB in several countries of the Region. The low prevalence of EB may have negative repercussions for the burden of disease in the Region. There is evidence that proper early infant nutrition may play an important role in the prevention of NCDs throughout life (128). EB in the first 6 months of life ensures adequate mental development and optimal physical growth, metabolic regulation and immunity (129). Several studies have also shown that breastfeeding lowers the risk of obesity in childhood and ensures a more linear pattern of growth in infancy (129).

The findings of this review show that several countries in the Region are still plagued with a high burden of undernutrition in young children. As per the WHO cutoffs (130), the levels of wasting were acceptable $(<5 \%)$ in only a few countries (Bahrain, the Islamic Republic of Iran, Jordan, Kuwait, Lebanon, Morocco, 
occupied Palestinian territory and Tunisia), while the regional average $(8.69 \%)$ exceeded $5 \%$. The regional average was also found to exceed the global average of wasting $(7.7 \%)(131)$, as well as estimates reported from the USA (0.5\%) (131), but it was lower than those reported from Asia (9.9\%), excluding Japan (132). As for underweight, the regional average $(18 \%)$ was higher than that reported in 2004 (17\%), indicating that there has been no progress on this front (9). This regional average exceeds the global average of $14 \%$ (133), while it is lower than that reported from South Asia (29.8\%). In addition, an increasing trend in the prevalence of stunting was observed in Djibouti and Pakistan, highlighting an increased threat of chronic undernutrition in these countries. The annual rate of change in the regional prevalence of stunting was estimated at $-2.8 \%$, which was below the rate specified by the 2025 World Health Assembly global nutrition target (-3.9\%) (122). In fact, only a few countries appeared to be on the right track towards meeting the 2025 target for stunting, namely Bahrain $(-4.7 \%)$, Egypt (-4.3\%), the Islamic Republic of Iran $(-4.4 \%)$, Lebanon $(-6.2 \%)$, Morocco $(-5.1 \%)$ and the occupied Palestinian territory $(-8 \%)$. The regional average of stunting $(28 \%)$ exceeded estimates reported from Europe (6.1\%) (134) and the USA (2.1\%) (135), although it was close to the worldwide average of $22.9 \%$ (135).

Anaemia, another hallmark of undernutrition among children and women of reproductive age, appears to be a persistent challenge in the Region, although some countries have witnessed progress in this indicator. For instance, in Morocco, a country that has implemented iron fortification of flour, the prevalence of anaemia among children aged 2-5 years decreased by $37.4 \%$ between 2006 and 2008 (136). Similarly, in Jordan, after the implementation of wheat flour fortification with multiple micronutrients, including iron, anaemia prevalence decreased from $40.4 \%$ in 2007 to $33.9 \%$ in 2009 among children aged 6-59 months (137).

The persistent burden of undernutrition in the Region may be linked to various environmental, economic and political factors. Food security is threatened by scarce freshwater resources, arid climate, high dependence on imports, limited productive economic diversification, high unemployment rates and income inequalities (138). The political unrest in many countries of the Region has contributed to further destabilization of the food security safety nets, livelihood and agricultural production. In fact, countries experiencing political turmoil have witnessed an increase in the prevalence of undernutrition over time. Moreover, food security appears as an economic challenge in the Region; the World Bank estimates that $5 \%$ of the Region's population is below the US\$1.25-aday poverty line and suffers from numerous forms of deprivation, including malnutrition, and that the number of people afflicted with poverty had increased by 2.6 million by 2011 (139). The burden of undernutrition in the Region calls for action by all countries to end all forms of food insecurity, build economic growth and alleviate poverty, as highlighted by the Sustainable Development
Agenda (140). This may be particularly challenging to several countries that are currently facing armed conflict and political instability, while harbouring significant numbers of displaced people and forced population movements. These sociopolitical dimensions magnify the threat of food insecurity and nutritional inadequacies, particularly among the vulnerable and poorer segments of the population (8). In conformity with international law and the Sustainable Development Agenda, further effective measures and actions are needed to "remove obstacles and constraints, strengthen support and meet the special needs of people living in areas affected by complex humanitarian emergencies", political turmoil and armed conflict (141).

This review also shows that, in all countries of the Region, undernutrition coexists with overnutrition, as assessed by obesity and overweight. The results highlight a high prevalence and increasing trend of adult obesity in many countries (44,87-90). The regional average of adult obesity (24\%) exceeds the worldwide average (9.8\% in men and $13.8 \%$ in women) (142), as well as estimates reported from South Asia (1.2-2.9\%), but it is lower than the average prevalence of adult obesity in North America (29.2\%) (142). Possible determinants of adult obesity in the Region include higher energy intakes, higher intakes of sugar-sweetened beverages, larger food portion sizes, low intakes of fruits and vegetables, physical inactivity and sedentary lifestyle, cultural norms and food subsidy policy $(112,143,144)$. The escalating burden of adult obesity may have serious public health implications, given the positive associations between weight gain and NCDs $(93,145)$, and that the Region already suffers from a high NCD burden, which accounts for $>50 \%$ of annual deaths (146). According to the WHO, deaths from NCDs were projected to increase by $25 \%$ between 2008 and 2018 in the Region, reflecting the second highest projected increase amongst the 6 WHO regions (147,148).

This review underlines the high burden and alarming increase in the prevalence of paediatric obesity in the Region. Among school-age children and adolescents, the annual rate of change in obesity prevalence exceeded in some countries, such as Bahrain (14.8\% in girls), Tunisia (13.5\%) and Qatar (13\% in boys and $12.7 \%$ in girls), the predictions made by Wang and Lobstein for the Region (5.6\%) (149). The prevalence of obesity among school-age children in Kuwait (29.6\%), Bahrain (21.7\%) and the UAE (14.4\%) exceeds estimates reported from Europe (6.8$7.3 \%)$ (150) and the USA (18.7\%) (151). Among children aged $<5$ years, the prevalence of overweight/obesity increased in several countries, including Afghanistan, the Islamic Republic of Iran, Kuwait, Libya, Oman, Pakistan, Qatar, Saudi Arabia and Tunisia, with the highest annual rates of increase being observed in Saudi Arabia (37.1\%), Libya (11.1\%) and Tunisia (10.4\%). The estimated regional average for overweight and obesity among children aged $<5$ years was $8.42 \%$, which exceeds the worldwide average $(6.7 \%)$ and that reported for Asia (4.9\%) and developing countries (6.1\%), but it was lower than estimates reported for developed countries (11.7\%) (118). The growing epidemic 
of childhood obesity is a major public health concern, given that paediatric obesity has been shown to track into adulthood and predict a broad range of metabolic and psychological adverse health effects $(152,153)$. Studies of the association of childhood obesity with socioeconomic, dietary and lifestyle factors have highlighted the following risk factors: higher socioeconomic status $(154,155)$; urban residence (156); parental obesity $(154,157)$, maternal BMI (155,158); television viewing (154); high sugar intake (155); high fat intake $(155,156)$; high frequency of consumption of sugar-sweetened beverages and of fast foods $(156,159)$; low consumption of vegetables, fruit and dairy products (156); and high frequency of eating out $(156,160)$. Given the established link between paediatric obesity, the consumption of high-energy, high-sugar, high-fat foods and the marketing of such foods to children, the WHO Regional Office for the Eastern Mediterranean Region has recently released a regional nutrient profiling model designed for use by governments for the purposes of restricting food marketing to children (161).

Most countries in the Region are witnessing fast rates of development and modernization, with concurrent shifts in diet and food consumption (162). These shifts are the basis of the nutritional transition, which is characterized by increased intake of energy, fat, added sugars and salty foods $(162,163)$. Through these particular changes in dietary intake, the nutritional transition may explain the escalating burden of obesity and NCDs in the Region (162-164). Food availability data highlight a shift towards an increasingly energy-dense diet and higher intake of fat in the Region, with a parallel decreasing trend in carbohydrate availability. This trend is confirmed by dietary assessment surveys, which also document high intake of fat, and a shift towards a westernized diet $(159,162,165-168)$. Nearly half of the countries in the Region had fat supply levels at or above the reported global average of $81.8 \mathrm{~g} /$ person/day (169). The observed increasing trend in fat supply is worrying, given that available evidence highlights probable associations between fat intake, obesity and various NCDs (170).

While this review provides valuable insight into the nutritional situation of the Region, its findings should be viewed in light of the following limitations. The available data on nutritional indicators were, in many instances, limited by the scarcity of recent and nationally representative studies examining the nutritional status of the population in many countries of the Region, and the scarcity of studies examining secular trends in nutritional indicators. Limited research funding, political instability and conflict are a few of the challenges that some countries are facing and that may contribute to the paucity of data.

\section{Recommendations}

This review responds to the increasing demand to conduct research on research, to understand better what is already known, and to guide and inform better the development of policies and interventions (171). As such, the work undertaken in this review calls for immediate action to address the double burden of malnutrition in countries of the Region. Priority interventions should aim at improving the nutritional status of the population, particularly among vulnerable population groups, including children and women of reproductive age. The persistence of LBW and child undernutrition highlight the need for government-led interventions that apply a food systems approach in tackling malnutrition to meet the global nutrition targets by 2025. Similarly, given the observed low rates of $\mathrm{EB}$, there is a need to protect, promote and support breastfeeding through the implementation of multisectoral interventions in the Region, including the development of effective culture-specific education and communication strategies. National legislation should implement the International Code of Marketing of BreastMilk Substitutes and relevant World Health Assembly resolutions, with effective monitoring and enforcement. The shifts in diet witnessed by most countries of the Region, coupled with the increase in the prevalence of obesity in all age groups, highlight the urgent need to instigate government-led reformulation programmes to reduce the levels of fat and sugars in foods and drinks, implement the WHO's recommendations to restrict marketing of foods high in fat or sugar to children, and develop relevant food taxation policies (172-174). The high rates of maternal obesity and anaemia highlight the need for interventions aimed at improving maternal nutrition, given the accumulating evidence linking maternal nutritional status to increased risk of NCDs in the offspring (175). In a region that is plagued by one of the highest burdens of NCDs worldwide, nutritional, impact-driven interventions should be placed at the forefront of national agendas, not only to address all forms of malnutrition, but also to contribute towards the achievement of many Sustainable Development Goals targets, including ending poverty, ensuring healthy lives, promoting lifelong learning, improving economic growth, building inclusive societies and ensuring sustainable consumption (176).

Funding: None.

Competing interests: None declared. 


\section{Examen de la situation nutritionnelle dans la Région de la Méditerranée orientale}

\section{Résumé}

L'analyse de la situation de la Région OMS de la Méditerranée orientale se concentre sur des indicateurs spécifiques relatifs à la nutrition, à savoir l'insuffisance pondérale à la naissance, l'allaitement au sein exclusif, la dénutrition et la suralimentation (indicateurs anthropométriques) et l'anémie. La prévalence régionale moyenne de l'insuffisance pondérale à la naissance et de l'allaitement au sein exclusif a été estimée à $19,31 \%$ et $29,3 \%$ respectivement. Le retard de croissance, l'émaciation, le déficit pondéral avaient une prévalence de $28 \%, 8,69 \%$ et $18 \%$ respectivement. L'Afghanistan, Djibouti, le Pakistan, le Soudan et le Yémen avaient la charge la plus lourde pour le retard de croissance (plus de $30 \%$ ). La prévalence de l'anémie était comprise entre 7,4 \% et $88 \%$ chez les enfants de moins de cinq ans, et entre $19,9 \%$ et $63 \%$ pour les femmes en âge de procréer. L'augmentation de la tendance à la surcharge pondérale et à l'obésité chez l'adulte et l'enfant est préoccupante. La prévalence moyenne de la surcharge pondérale et de l'obésité était de $27 \%$ et de $24 \%$ chez les adultes, et de $16,5 \%$ et $4,8 \%$ chez les enfants scolarisés respectivement. Les taux d'obésité les plus élevés ont été signalés à Bahreïn, aux Émirats arabes unis, au Koweït et au Qatar. Cette analyse souligne la double charge de la malnutrition dans les pays de la Région, et appelle à donner la priorité aux politiques visant à améliorer la situation nutritionnelle des populations.

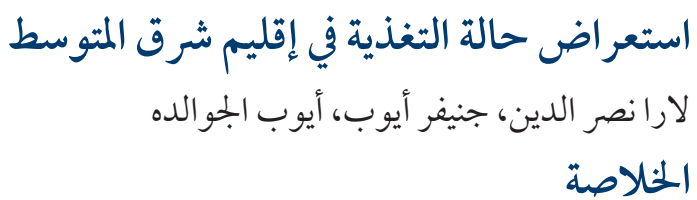

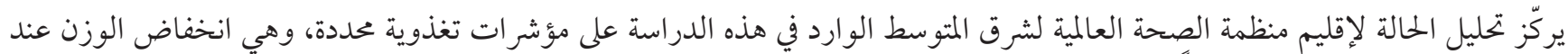

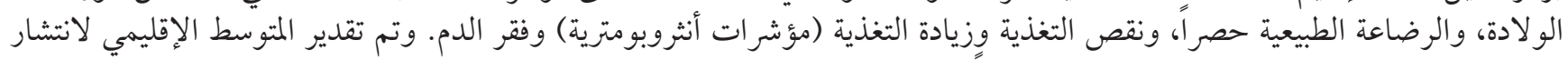

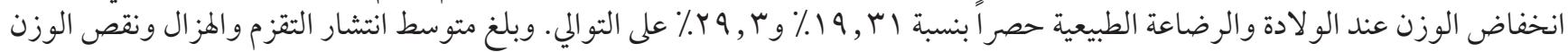

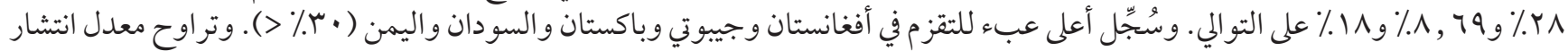

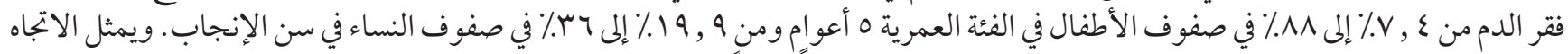

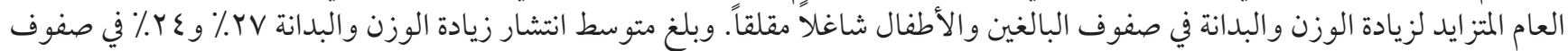

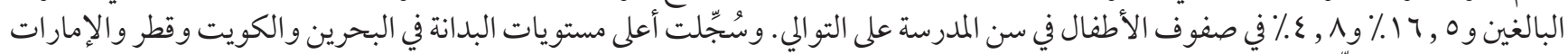

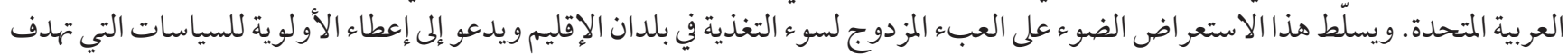
إلى تحسين الوضع التغذوي للسكان.

\section{References}

1. Food systems and diets: facing the challenges of the 21st century. Global Panel on Agriculture and Food Systems for Nutrition; 2016 (https://glopan.org/sites/default/files/ForesightReport.pdf, accessed 24 January 2018).

2. UNICEF's approach to scaling up nutrition for mothers and their children. United Nations Children's Fund; 2015 (https://www. unicef.org/nutrition/files/Unicef_Nutrition_Strategy.pdf, accessed 24 January 2018).

3. Black RE, Victora CG, Walker SP, Bhutta ZA, Christian P, de Onis M, et al.; Maternal and Child Nutrition Study Group. Maternal and child undernutrition and overweight in low-income and middle-income countries. Lancet. 2013 Aug 3;382(9890):427-51. https://doi.org/10.1016/S0140-6736(13)60937-X PMID:23746772

4. Itoh H, Kanayama N. Nutritional conditions in early life and risk of non-communicable diseases (NCDs) from the perspective of preemptive medicine in perinatal care. Hypertens Res Pregnancy. 2015;3(1):1-12. https://doi.org/10.14390/jsshp.3.1

5. Olofin I, McDonald CM, Ezzati M, Flaxman S, Black RE, Fawzi WW, et al.; Nutrition Impact Model Study (anthropometry cohort pooling). Associations of suboptimal growth with all-cause and cause-specific mortality in children under five years: a pooled analysis of ten prospective studies. PLoS One. 2013 May 29;8(5):e64636. https://doi.org/10.1371/journal.pone.0064636 PMID:23734210

6. Bloom D, Cafiero E, Jané-Llopis E, Abrahams-Gessel S, Bloom L, Fathima S et al. The global economic burden of noncommunicable diseases. Geneva: World Economic Forum; 2011 (http://apps.who.int/medicinedocs/documents/s18806en/ s18806en.pdf, accessed 24 January 2018).

7. Hruby A, Hu FB. The epidemiology of obesity: a big picture. Pharmacoeconomics. 2015 Jul;33(7):673-89. https://doi.org/10.1007/ S40273-014-0243-x PMID:25471927

8. Food and Agriculture Organization of the United Nations. Second International Conference on Nutrition (ICN 2). Conference Outcome Document: Rome Declaration on Nutrition; 2014 (http://www.fao.org/3/a-ml542e.pdf, accessed 24 January 2018).

9. Technical paper. Regional strategy on nutrition 2010-2019. World Health Organization. Regional Office for the Eastern Mediterranean; 2010 (http://applications.emro.who.int/docs/EM_RC57_4_en.pdf , accessed 5 February 2018). 
10. Morrison JL, Regnault TR. Nutrition in pregnancy: optimising maternal diet and fetal adaptations to altered nutrient supply. Nutrients. 2016 Jun 4;8(6). pii: E342. http://dx.doi.org/10.3390/nu8060342 PMID:27271666

11. Das JK, Salam RA, Imdad A, Bhutta ZA. Infant and young child growth. In: Black RE, Laxminarayan R, Temmerman M, et al., editors. Reproductive, maternal, newborn, and child health: disease control priorities, third edition (volume 2). Washington (DC): The International Bank for Reconstruction and Development/World Bank

12. Underlying causes of undernutrition: food insecurity. United Nations Children's Fund (http://www.unicef.org/nutrition/ training/2.5/9.html, accessed 24 January 2018).

13. Tette EM, Sifah EK, Nartey ET. Factors affecting malnutrition in children and the uptake of interventions to prevent the condition. BMC Pediatr. 201511 19;15(1):189. https://doi.org/10.1186/s12887-015-0496-3 PMID:26586172

14. Nutrition: strategy and policy. World Health Organization Regional Office for the Eastern Mediterranean (http://www.emro.who. int/nutrition/strategy/,accessed 5 February 2018).

15. Nair MK, Augustine LF, Konapur A. Food-based interventions to modify diet quality and diversity to address multiple micronutrient deficiency. Front Public Health. 2016 01 5;3:277. https://doi.org/10.3389/fpubh.2015.00277 PMID:26779472

16. Country groupings: Subregional country groupings for the global assessment of disease burden. World Health Organization; 2001 (http://www.who.int/quantifying_ehimpacts/global/ebdcountgroup/en/, accessed 24 January 2018).

17. The World Health Organization's infant feeding recommendation. World Health Organization; 2015 (http://www.who.int/ nutrition/topics/infantfeeding_recommendation/en/, accessed 24 January 2018).

18. UNICEF data: monitoring the situation of children and women. Undernourishment in the womb can lead to diminished potential and predispose infants to early death. United Nations Children's Fund; 2014 (https://data.unicef.org/topic/nutrition/ low-birthweight/, accessed 5 February 2018)

19. WHO Multicentre Growth Reference Study Group. WHO child growth standards based on length/height, weight and age. Acta Paediatr Suppl. 2006 Apr;450:76-85. PMID:16817681

20. de Benoist B, McLean E, Egli I, Cogswell M, editors. Worldwide prevalence of anaemia 1993-2005: WHO global database on anaemia. Geneva: World Health Organization; 2008 (http://apps.who.int/iris/bitstream/10665/43894/1/9789241596657_eng. pdf?ua=1, accessed 24 January 2018).

21. BMI-for-age (5-19 years). World Health Organization (http://www.who.int/growthref/who2007_bmi_for_age/en/, accessed 24 January 2018).

22. Global database on body mass index: BMI classification. World Health Organization; 2006 (http://apps.who.int/bmi/index. jsp?introPage=intro_3.html), accessed 5 February 2018).

23. FAOSTAT. Food balance sheets. Food and Agriculture Organization of the United Nations (http://faostat.fao.org/en/\#data/FBS, accessed 5 February 2018).

24. Chronic diseases and health promotion. STEPS Country Reports. World Health Organization; 2017 (http://www.who.int/ncds/ surveillance/steps/reports/en/, accessed 9 June 2017).

25. Chronic diseases and health promotion. Global school-based student health survey (GSHS) implementation. World Health Organization; 2017 (http://www.who.int/ncds/surveillance/gshs/country/en/, accessed 9 June 2017).

26. Global database on child growth and malnutrition. World Health Organization (http://www.who.int/nutgrowthdb/en/, accessed 24 January 2018).

27. Multiple Indicator Cluster Surveys (MICS). United Nations Children's Fund (http://mics.unicef.org/surveys, accessed 24 January 2018).

28. Food and nutrition in numbers 2014. Rome: Food and Agriculture Organization of the United Nations; 2014 (http://www.fao. org/3/a-i4175e.pdf, accessed 24 January 2018).

29. Yemen National Reproductive Health Strategy 2011-2015. Ministry of Public Health and Population, Republic of Yemen; 2011.

30. Ministère de la Santé [Maroc]. Enquête sur la Population et la Santé Familiale (EPSF) 2003-2004. Calverton, MD: Ministère de la Santé et ORC Macro; 2005 (http://dhsprogram.com/pubs/pdf/FR155/FR155.pdf, accessed 24 January 2018) (in French).

31. United Nations Children's Fund and World Health Organization. Low birthweight: country, regional and global estimates. New York: UNICEF; 2004 (http://whqlibdoc.who.int/publications/2004/9280638327.pdf, accessed 24 January 2018).

32. Country Profile. Oman. Maternal, newborn \& child survival. Statistics and Monitoring Section/Policy and Practice, United Nations Children's Fund; 2012 (https://data.unicef.org/wp-content/uploads/country_profiles/Oman/Maternal_OMN.pdf, accessed 24 January 2018).

33. Somali nutrition strategy 2011-2013. Towards the Millennium Development Goals. World Health Organization/UNICEF/WFP/ FAO/FSNAU; 2010 (https://www.humanitarianresponse.info/system/files/SOMALIA_NUTRITION_STRATEGY_2011-2013.pdf, accessed 24 January 2018).

34. Somaliland. Monitoring the situation of children and women. Summary Preliminary Results Multiple Indicator Cluster Survey 2011. United Nations Children's Fund/MICS; 2011 (https://www.unicef.org/somalia/SOM_resources_somalilandmics4sum. pdf,accessed 24 January 2018).

35. Kassim I, Seal A, Moloney G. National micronutrient and anthropometric survey, Somalia 2009; 2010 (http://www. humanitarianresponse.info/system/files/Somalia-National-Micronutrient-Study.pdf, accessed 24 January 2018). 
36. Ministry of Development and International Cooperation. National Institute of Statistics and United Nations Children's Fund. Monitoring the situation of children and women in Tunisia - MICS 2011-2012; 2013 (https://mics-surveys-prod.s3.amazonaws. com/MICS4/Middle\%20East\%20and\%20North\%20Africa/Tunisia/2011-2012/Final/Tunisia\%202011-12\%20MICS_French.pdf, accessed 24 January 2018) (in French).

37. Yemen Family Health Survey 2003. Ministry of Public Health and Population, Yemen (http://www.mophp-ye.org/arabic/docs/ Familyhealth_english.pdf, accessed 24 January 2018).

38. Multiple Indicators Cluster Survey round 3 (MICS3). Central Administration of Statistics in collaboration with UNICEF, Lebanon; 2009. (http://www.cas.gov.lb/images/Mics3/CAS_MICS3_survey_2009.pdf, accessed 5 February 2018) (in Arabic)

39. State of Qatar. Monitoring the situation of children and women. Multiple Indicator Cluster Survey 2012. Ministry of Development Planning and Statistics, Qatar; 2014 (https://www.mdps.gov.qa/en/statistics/Surveys/MICS-2012-Eng.pdf, accessed 24 January 2018).

40. Qatar health profile 2015. Cairo: World Health Organization Regional Office for the Eastern Mediterranean; 2016 (http:// applications.emro.who.int/dsaf/EMROPUB_2016_EN_18927.pdf, accessed 5 February 2018).

41. Global Health Observatory Data Repository. Exclusive breastfeeding under 6 months: data by country. World Health Organization (http://apps.who.int/gho/data/view.main.NUT1730?lang=eng, accessed 24 January 2018).

42. Jordan Population and Family Health Survey 2012. Calverton, MD: Department of Statistics and ICF International; 2013 (https:// dhsprogram.com/pubs/pdf/FR282/FR282.pdf, accessed 24 January 2018).

43. Geneva Infant Feeding Association (IBFAN-GIFA) IBFAN global liason office. The Convention on the Rights of the Child, Session 67/September 2014. Report on the situation of infant and young child feeding in Morocco. International Baby Food Action Network; 2014 (http://tbinternet.ohchr.org/Treaties/CRC/Shared\%20Documents/MAR/INT_CRC_NGO_MAR_17890_E.pdf, accessed 24 January 2018).

44. National nutrition survey Afghanistan (2013): survey report. Afghanistan Ministry of Public Health/United Nations Children's Fund; 2013 (https://www.humanitarianresponse.info/system/files/documents/files/Report\%20NNS\%20Afghanistan\%202013\%20 \%28July\%2026-14\%29.pdf, accessed 24 January 2018).

45. Kalantari N, Haghighian Roudsari A. Breastfeeding promotion in Iran: opportunities and challenges. J Comprehens Pediatr. 2013;3(4):165-6. https://doi.org/10.17795/compreped-12327

46. UNICEF Annual Report 2013 - Djibouti; 2013 (http://www.unicef.org/about/annualreport/files/Djibouti_COAR_2013.pdf, accessed 24 January 2018).

47. El-Zanaty F, Way AA. Egypt Interim Demographic and Health Survey 2003. Cairo: Ministry of Health and Population (Egypt) National Population Council, El-Zanaty and Associates and ORC Macro; 2004 (https://dhsprogram.com/pubs/pdf/FR149/FR149. pdf, accessed 24 January 2018).

48. Batal M, Boulghourjian C, Abdallah A, Afifi R. Breast-feeding and feeding practices of infants in a developing country: a national survey in Lebanon. Public Health Nutr. 2006 May;9(3):313-9. https://doi.org/10.1079/PHN2006860 PMID:16684382

49. Central Bureau of Statistics and UNICEF. Preliminary report on the Multiple Cluster Survey on the Situation of Children in Lebanon; 2001 (http://mics.unicef.org/surveys, accessed 27 June 2017).

50. Sudan Maternal and Child Health Survey 1992-1993. Ministry of Health, Sudan and Pan Arab Project for Child Development; 1995.

51. Sudan Household Health Survey - Round 2, 2010. National Report December 2012. Federal Ministry of Health and Central Bureau of Statistics, Government of Sudan; 2012 (https://mics-surveys-prod.s3.amazonaws.com/MICS4/Middle\%20East\%20 and\%20North\%20Africa/Sudan/2010/Final/Sudan\%202010\%20MICS_English.pdf, accessed 24 January 2018).

52. UNICEF. Somalia - Multiple Indicator Cluster Survey 1999. National Statistics Office, Somalia; 1999.

53. Yemen Demographic and Maternal and Child Health Survey 1997. Sana’a: Central Statistical Organization; Calverton, MD: Macro International; 1998 (http://dhsprogram.com/pubs/pdf/FR94/FR94.pdf, accessed 24 January 2018).

54. Egypt Demographic and Health Survey 2014. Main findings. Cairo: Ministry of Health and Population; Cairo: El-Zanaty and Associates; Rockville, MD: DHS Program/ICF International; 2014 (http://dhsprogram.com/pubs/pdf/PR54/PR54.pdf, accessed 24 January 2018

55. Multiple Indicator Cluster Survey for the Year 2000 (detailed report). Baghdad: Council of Ministers, Planning Commission, Central Statistical Organisation; United Nations Children's Fund; 2001 (https://www.unicef.org/iraq/Iraq_2000_MICS_Report.pdf, accessed24 January 2018).

56. Pakistan Demographic and Health Survey 1990/1991. Islamabad: National Institute of Population Studies; Columbia, MD: DHS, IRD/Macro International; 1992 (https://www.dhsprogram.com/pubs/pdf/FR29/FR29.pdf, accessed 24 January 2018).

57. Palestinian Multiple Indicator Cluster Survey 2014. Final report December 2015. Ramallah: Palestinian Central Bureau of Statistics; United Nations Children's Fund; United Nations Population Fund; 2015 (http://www.pcbs.gov.ps/Downloads/book2175. pdf, accessed 24 January 2018).

58. Final Report of the Palestinian Family Survey 2010. Final report. Ramallah: Palestinian Central Bureau of Statistics; 2013 (http:// www.pcbs.gov.ps/Downloads/book1941.pdf, accessed 24 January 2018). 
59. Yemen National Health and Demographic Survey 2013. Preliminary report. Sana'a: Ministry of Public Health and Population and Central Statistical Organization; 2014 (http://pdf.usaid.gov/pdf_docs/pbaaa661.pdf, accessed 24 January 2018).

60. Monitoring the situation of women and children. Somalia Multiple Indicator Cluster Survey 2006. New York: United Nations Children's Fund; 2007.

61. Global Database on Child Growth and Malnutrition. Countries and territories. World Health Organization; 2015 (http://www. who.int/nutgrowthdb/database/countries/en/, accessed 24 January 2018).

62. Iraq. Monitoring the situation of women and children. Multiple Indicator Cluster Survey 2011. Volume 1: final report. Baghdad: Central Statistics Organization and Kurdistan Regional Statistics Office. 2012 (https://mics-surveys-prod.s3.amazonaws.com/ MICS4/Middle\%20East\%20and\%20North\%20Africa/Iraq/2011/Final/Iraq\%202011\%20MICS_English.pdf, accessed 5 February 2018)

63. Iraq. Monitoring the situation of women and children. Multiple Indicator Cluster Survey 2006. Volume 1: final report. Baghdad: Central Statistics Organization and Kurdistan Regional Statistics Office; 2007 (https://mics-surveys-prod.s3.amazonaws.com/ MICS3/Middle\%20East\%20and\%20North\%20Africa/Iraq/2006/Final/Iraq\%202006\%20MICS_English.pdf, accessed 5 February 2018))

64. National Center for Infectious and Chronic Disease Control [Jamahiriya] and Pan-Arab Project for Family Health. National Libyan family health survey. PAPFAM surveys. Cairo: The League of Arab States; 2008.

65. Libyan Maternal and Child Health Survey. PAPCHILD Surveys. Cairo: The League of Arab States; 1997.

66. El-Zanaty F, Way A. Egypt Demographic And Health Survey 2008. Cairo: Ministry of Health; El-Zanaty and Associates; Calverton, MD: Macro International; 2009 (https://dhsprogram.com/pubs/pdf/fr220/fr220.pdf, accessed 24 January 2018).

67. Sudan Household Health Survey (SHHS) 2006. Khartoum and Juba: Government of National Unity; 2007.

68. Enquête Djiboutienne à Indicateurs Multiples (EDIM): Rapport preliminaire. Djibouti: Ministère de la Santé; Pan Arab Family Health Survey; 2013 (http://docplayer.fr/18402852-Edim-enquete-djiboutienne-a-indicateurs-multiples.html, accessed 24 January 2018) (in French).

69. Department of Statistics, Demographic Studies, Ministry of Health and Pan Arab Project for Family Health. Enquête djiboutienne sur la santé de la famille (EDSF/PAPFAM) 2002, PAPFAM Rapport final. Djibouti; 2004.

70. The family health survey in the Syrian Arab Republic. League of Arab States; Pan Arab Project for Family Health; Central Bureau of Statistics, Syrian Arab Republic; 2002 (http://s3.amazonaws.com/zanran_storage/www.un.org.sy/ContentPages/47530865.pdf, accessed 24 January 2018).

71. ICF International. Pakistan Demographic and Health Survey 2012-13. Demographic and Health Surveys, Islamabad: National Institute of Population Studies; Calverton, MD: ICF International; 2013 (https://dhsprogram.com/pubs/pdf/fr290/fr290.pdf, accessed 24 January 2018).

72. Ministère de la Santé et PAPFAM. Enquête Djiboutienne à Indicateurs Multiples (EDIM). Rapport final. Djibouti: Ministère de la Santé; Pan Arab Family Health Survey; 2007 (http://www.who.int/fctc/reporting/party_reports/djibouti_annexı_mics_ report_2006_fr.pdf, accessed 24 January 2018) (in French).

73. Bhutta Z, Soofi S, Zaidi S, Habib A, Hussain M. Pakistan National Nutrition Survey, 2011. Aga Khan University, Pakistan; Pakistan Medical Research Council; Nutrition Wing, Cabinet Division, Government of Pakistan; 2011 (https://ecommons.aku.edu/cgi/ viewcontent.cgi?referer=https://www.google.co.uk/\&httpsredir=1\&article=1262\&context=pakistan_fhs_mc_women_childhealth_ paediatr, accessed 24 January 2018).

74. Pakistan Institute of Development Economics, Micro-nutrient Laboratories Aga Khan University and Medical Centre Karachi. National Nutrition Survey 2001-2002. Islamabad: Planning Commission, Government of Pakistan and UNICEF; 2004.

75. Federal Ministry of Health, Federal Ministry of Agriculture and Irrigation, Food and Agriculture Organization of the United Nations, World Health Organization, World Food Programme, United Nations Children's Fund. National Nutrition Strategy Paper Sudan, English Version. FAO/WHO Second International Conference on Nutrition ICN2; 2015 (http://docs. scalingupnutrition.org/wp-content/uploads/2016/08/3.-Sudan-Nutrition-strategic-apaer-ICN_2.pdf, accessed 24 January 2018).

76. Al-Riyami A, Afifi M, Al-Kharusi H, Morsi M. National Health Survey, 200o. Reproductive Health Study. Volume II. Oman: Ministry of Health; 2000.

77. Verster A, van der Pols JC. Anaemia in the Eastern Mediterranean Region. East Mediterr Health J. 1995;1(1) (http://www.emro.who. int/emhj-volume-1-1995/volume-1-issue-1/article8.html).

78. Saeed KMI. Prevalence and associated risk factors for obesity in Jalalabad city -Afghanistan. Alexandria J Med. 2015 Dec;51(4):347-52. https://doi.org/10.1016/j.ajme.2014.12.004

79. National Non-communicable Diseases Risk Factors Survey 2007. Kingdom of Bahrain Ministry of Health; 2010 (http://www.who. int/ncds/surveillance/steps/2007_STEPS_Survey_Bahrain.pdf, accessed 5 February 2018).

80. Egypt STEPS Survey 2011-12. Fact sheet. WHO STEPS chronic disease risk factor surveillance (6-3C-1) (http://www.who.int/chp/ steps/2011-2012_Egypt_FactSheet.pdf?ua=1, accessed 245 January 2018).

81. IRAN STEPS Survey 2009. Fact sheet 1388 (http://www.who.int/chp/steps/Iran_2009_STEPS_FactSheet.pdf?ua=1, accessed 25 January 2018). 
82. Iraq STEPS Survey 2006. Fact sheet (http://www.who.int/chp/steps/Iraq_2006_STEPS_FactSheet.pdf?ua=1, accessed 25 January 2018).

83. Qatar STEPS Survey 2012. Fact sheet. WHO STEPS chronic disease risk factor surveillance (6-3C-1) (http://www.who.int/chp/ steps/Qatar_FactSheet_2012.pdf?ua=1, accessed 25 January 2018).

84. Malik M, Bakir A, Saab BA, King H. Glucose intolerance and associated factors in the multi-ethnic population of the United Arab Emirates: results of a national survey. Diabetes Res Clin Pract. 2005 Aug;69(2):188-95. https://doi.org/10.1016/j.diabres.2004.12.005 PMID:16005369

85. 2009 STEPS Survey Report (Arabic). National Survey of Non-Communicable Disease Risk Factors; 2009 (http://www.who.int/chp/ steps/2009_STEPS_Libya.pdf?ua=1, accessed 25 January 2018).

86. Gunaid A. Obesity, overweight and underweight among adults in an urban community in Yemen. East Mediterr Health J. 2012 Dec;18(12):1187-93. PMID:23301392

87. Sheikh-Ismail LI, Henry CJK, Lightowler HJ, Aldhaheri AS, Masuadi E, Al Hourani HM. Prevalence of overweight and obesity among adult females in the United Arab Emirates. Int J Food Sci Nutr. 2009;60(Suppl 3):26-33. https://doi. org/10.1080/09637480802331179 PMID:18946797

88. Ng SW, Zaghloul S, Ali H, Harrison G, Yeatts K, El Sadig M, et al. Nutrition transition in the United Arab Emirates. Eur J Clin Nutr. 2011 Dec;65(12):1328-37. https://doi.org/10.1038/ejcn.2011.135 PMID:21772317

89. El Ati J, Traissac P, Delpeuch F, Aounallah-Skhiri H, Béji C, Eymard-Duvernay S, et al. Gender obesity inequities are huge but differ greatly according to environment and socio-economics in a North African setting: a national cross-sectional study in Tunisia. PLoS One. 2012;7(10):e48153. https://doi.org/10.1371/journal.pone.0048153 PMID:23118943

90. Mokhtar N, Elati J, Chabir R, Bour A, Elkari K, Schlossman NP, et al. Diet culture and obesity in northern Africa. J Nutr. 2001 Mar;131(3):887S-92S. https://doi.org/10.1093/jn/131.3.887S PMID:11238780

91. Ahmed F, Waslien C, Al-Sumaie MA, Prakash P. Secular trends and risk factors of overweight and obesity among Kuwaiti adults: National Nutrition Surveillance System data from 1998 to 2009. Public Health Nutr. 2012 Nov;15(11):2124-30. https://doi. org/10.1017/S1368980011003685 PMID:22349029

92. Abdul Wahab AWM, Moosa K, Gharib N, Al-Sairafi M, Al-Raees G, Al-Amer M. National nutrition survey for adult Bahrainis aged 19 years and above. Ministry of Health, Kingdom of Bahrain; 2002.

93. Nasreddine L, Naja F, Chamieh MC, Adra N, Sibai A-M, Hwalla N. Trends in overweight and obesity in Lebanon: evidence from two national cross-sectional surveys (1997 and 2009). BMC Public Health. 201209 17;12(1):798. https://doi.org/10.1186/1471-2458-12798 PMID:22984791

94. Ellulu M, Rahmat A, Abed Y. Updates of overweight and obesity status and their consequences in Palestine. Pak J Nutr. 2014;13(2):116-21. https://doi.org/10.3923/pjn.2014.116.121

95. El Kishawi RR, Soo KL, Abed YA, Muda WA. Obesity and overweight: prevalence and associated socio demographic factors among mothers in three different areas in the Gaza Strip-Palestine: a cross-sectional study. BMC Obes. 2014 04 22;1(1):7. https:// doi.org/10.1186/2052-9538-1-7 PMID:26217499

96. Global School-based Student Health Survey. United Arab Emirates 2010 fact sheet (http://www.who.int/chp/gshs/UAE_2010_ FS.pdf, accessed 25 January 2018).

97. Global School-based Student Health Survey. Pakistan 2009 fact sheet (http://www.who.int/ncds/surveillance/gshs/ Pakistan_2009_FS.pdf?ua=1, accessed 5 February 2018)

98. Global School-based Student Health Survey. Morocco 2010 fact sheet (http://www.who.int/chp/gshs/Morocco_2010_GSHS_ FS.pdf?ua=1, accessed 25 January 2018).

99. Global School-based Student Health Survey. Sudan 2012 fact sheet (http://www.who.int/chp/gshs/2012_Sudan_GSHS FS.pdf?ua=1, accessed 25 January 2018).

100. Global School-based Student Health Survey. Yemen 2008 fact sheet (http://www.who.int/chp/gshs/2008_Yemen_fact_sheet. pdf?ua=1, accessed 25 January 2018).

101. Global School-based Student Health Survey. Djibouti 2007 fact sheet (http://www.who.int/chp/gshs/Djibouti_2007_Fact_Sheet. pdf?ua=1, accessed 25 January 2018).

102. Kelishadi R, Ardalan G, Gheiratmand R, Majdzadeh R, Hosseini M, Gouya MM, et al.; Caspian Study Group. Thinness, overweight and obesity in a national sample of Iranian children and adolescents: CASPIAN Study. Child Care Health Dev. 2008 Jan;34(1):44-54. PMID:18171443

103. Mirmohammadi S-J, Hafezi R, Mehrparvar AH, Rezaeian B, Akbari H. Prevalence of overweight and obesity among Iranian school children in different ethnicities. Iran J Pediatr. 2011 Dec;21(4):514-20. PMID:23056841

104. Bener A, Kamal AA. Growth patterns of Qatari school children and adolescents aged 6-18 years. J Health Popul Nutr. 2005 Sep;23(3):250-8. PMID:16262022

105. Rootwelt C, Beinnes Fosse K, Tuffaha A, Said H, Sandridge A, Janahi I, et al. Qatar's youth is putting on weight: the increase in obesity between 2003 and 2009. Qatar Foundation Annual Research Conference Proceedings: HBSP1130.

106. El-Hazmi MA, Warsy AS. A comparative study of prevalence of overweight and obesity in children in different provinces of Saudi Arabia. J Trop Pediatr. 2002 Jun;48(3):172-7. https://doi.org/10.1093/tropej/48.3.172 PMID:12164602 
107. Al-Almaie SM. Prevalence of obesity and overweight among Saudi adolescents in Eastern Saudi Arabia. Saudi Med J. 2005 Apr;26(4):607-11. PMID:15900370

108. Al-Nuaim AA, Al-Nakeeb Y, Lyons M, Al-Hazzaa HM, Nevill A, Collins P et al. The prevalence of physical activity and sedentary behaviours relative to obesity among adolescents from Al-Ahsa, Saudi Arabia: rural versus urban variations. J Nutr Metab. 2012;2012:417589. http://doi.org/10.1155/2012/417589 PMID:22315673

109. Aounallah-Skhiri H, El Ati J, Traissac P, Ben Romdhane H, Eymard-Duvernay S, Delpeuch F, et al. Blood pressure and associated factors in a North African adolescent population. a national cross-sectional study in Tunisia. BMC Public Health. 2012 Feb 3;12(1):98. https://doi.org/10.1186/1471-2458-12-98 PMID:22305045

110. Aounallah-Skhiri H, El Ati J, Traissac P, Ben Romdhane H, Bougatef S, Beji C, et al. Evolution de la consommation alimentaire et de la corpulence des adolescents tunisiens entre 1996 et 2005. 4ème Congrès de la Société Française de Nutrition, 10-12 décembre 2009.

111. Musaiger AO. The state of nutrition in Bahrain. Nutr Health. 2000;14(1):63-74. https://doi.org/10.1177/026010600001400107 PMID:10840814

112. Musaiger AO. Overweight and obesity in Eastern Mediterranean Region: prevalence and possible causes. J Obesity. 2011, Article ID 407237, 17 pages. http://dx.doi.org/10.1155/2011/407237

113. World Health Survey Qatar (https://static-content.springer.com/esm/art\%3A10.1186\%2F1478-7954-12-18/ MediaObjects/12963_2013_244_MOESM1_ESM.pdf, accessed 5 February 2018)

114. League of Arab States and Syrian Arab Republic. Family health survey of the Arab Republic of Syria 2009: Principal report (PAPFAM). Cairo: The League of Arab States; 2011.

115. Kuwait nutrition surveillance system report: trends: 2001-2005. Administration of Food and Nutrition, Ministry of Health, Kuwait; 2006

116. Kuwait nutrition surveillance system: 2006-2009 trends. Administration of Food and Nutrition, Ministry of Health, Kuwait; 2010.

117. Kuwait Nutrition Surveillance System [KNSS] 2010-2012. Administration of Food and Nutrition, Ministry of Health, Kuwait; 2013.

118. de Onis M, Blössner M, Borghi E. Global prevalence and trends of overweight and obesity among preschool children. Am J Clin Nutr. 2010 Nov;92(5):1257-64. https://doi.org/10.3945/ajcn.2010.29786 PMID:20861173

119. Alasfoor D. ASM, AlShamakhi S, Al Ghammari I. Second national PEM survey 2009. Muscat, Oman: Ministry of Health; 2011.

120. Ministère de la Santé Publique, Office National de la Famille et de la Population et UNICEF. Enquête sur la santé et le bien être de la mère et l'enfant: MICS 3. Tunis; 2008.

121. Low-birthweight babies (\% of births). World Bank (https://data.worldbank.org/indicator/SH.STA.BRTW.ZS, accessed 25 January 2018).

122. Indicator progress; World Health Organization (http://www.who.int/nutrition/indicator_progress.pdf, accessed 25 January 2018).

123. Hack M, Klein NK, Taylor HG. Long-term developmental outcomes of low birth weight infants. Future Child. 1995 Spring;5(1):176-96. https://doi.org/10.2307/1602514 PMID:7543353

124. Goldenberg RL, Culhane JF. Low birth weight in the United States. Am J Clin Nutr. 2007 Feb;85(2):584S-90S. PMID:17284760

125. Mahmoodi Z, Karimlou M, Sajjadi H, Dejman M, Vameghi M, Dolatian M, et al. Association of maternal working condition with low birth weight: the social determinants of health approach. Ann Med Health Sci Res. 2015 Nov-Dec;5(6):385-91. https://doi. org/10.4103/2141-9248.177982 PMID:27057375

126. Ahmad MO, Kalsoom U, Sughra U, Hadi U, Imran M. Effect of maternal anaemia on birth weight. J Ayub Med Coll Abbottabad. 2011 Jan-Mar;23(1):77-9. PMID:22830153

127. Muftah S. Maternal under-nutrition and anaemia factors associated with low birth weight babies in Yemen. Int J Commun Med Public Health. 2016;3:2749-56. https://doi.org/10.18203/2394-6040.ijcmph20163356

128. Balbus JM, Barouki R, Birnbaum LS, Etzel RA, Gluckman PD Sr, Grandjean P, et al. Early-life prevention of non-communicable diseases. Lancet. 2013 Jan 5;381(9860):3-4. https://doi.org/10.1016/So140-6736(12)61609-2 PMID:23290956

129. Guilloteau P, Zabielski R, Hammon HM, Metges CC. Adverse effects of nutritional programming during prenatal and early postnatal life, some aspects of regulation and potential prevention and treatments. J Physiol Pharmacol. 2009 Oct;60 Suppl 3:17-35. PMID:19996479

130. Nutrition Landscape Information System (NLIS): Country profile indicators interpretation guide. Geneva: World Health Organization; 2010 (http://www.who.int/nutrition/nlis_interpretation_guide.pdf, accessed 25 January 2018).

131. Prevalence of wasting, weight for height (\% of children under 5). World Bank (https://data.worldbank.org/indicator/SH.STA. WAST.ZS, accessed 25 January 2018).

132. Joint child malnutrition estimates - levels and trends (2017 edition). United Nations Children's Fund; World Health Organization; World Bank; 2017 (http://www.who.int/nutgrowthdb/estimates2016/en/, accessed 25 January 2018).

133. Prevalence of underweight, weight for age (\% of children under 5). World Bank (https://data.worldbank.org/indicator/SH.STA. MALN.ZS, accessed 25 January 2018). 
134. Prevalence of stunting in children under 5. World Health Organization (http://apps.who.int/gho/data/node.sdg.2-2-viz-1?lang=en, accessed 25 January 2018).

135. Prevalence of stunting, height for age (\% of children under 5). World Bank (https://data.worldbank.org/indicator/SH.STA.STNT. ZS, accessed 25 January 2018).

136. El Hamdouchi A, El Kari K, Rjimati L, El Haloui N, El Mzibri M, Aguenaou H, et al. [Impact of flour fortification with elemental iron on the prevalence of anaemia among preschool children in Morocco]. East Mediterr Health J. 2010 Nov;16(11):1148-52 (in French). PMID:21222324

137. Al Rifai R, Nakamura K, Seino K. Decline in the prevalence of anaemia among children of pre-school age after implementation of wheat flour fortification with multiple micronutrients in Jordan. Public Health Nutr. 2016 Jun;19(8):1486-97. https://doi. org/10.1017/S1368980015002785 PMID:26434612

138. Food security and conflict in the ESCWA Region. United Nations Economic and Social Commission for Western Asia; 2010 (https://www.unescwa.org/publications/food-security-and-conflict-escwa-region, accessed 25 January 2018).

139. Ivanic M, Martin W. Implications of higher global food prices for poverty in low-income countries. Policy Research Working Paper no. 4594. Washington, DC: World Bank; 2008 (https://openknowledge.worldbank.org/bitstream/handle/10986/6723/ wps4594.pdf?sequence $=1 \% 29 / /$ GP, accessed 5 February 2018).

140. Sustainable development goals: 17 goals to transform our world. United Nations. (http://www.un.org/sustainabledevelopment/ development-agenda/, accessed 25 January 2018).

141. Transforming our world: the 2030 Agenda for Sustainable Development. United Nations (https://sustainabledevelopment.un.org/ post2015/transformingourworld, accessed 25 January 2018).

142. Finucane MM, Stevens GA, Cowan MJ, Danaei G, Lin JK, Paciorek CJ, et al.; Global Burden of Metabolic Risk Factors of Chronic Diseases Collaborating Group (Body Mass Index). National, regional, and global trends in body-mass index since 1980: systematic analysis of health examination surveys and epidemiological studies with 960 country-years and 9.1 million participants. Lancet. 2011 Feb 12;377(9765):557-67. https://doi.org/10.1016/S0140-6736(10)62037-5 PMID:21295846

143. Musaiger AO, Al-Hazzaa HM. Prevalence and risk factors associated with nutrition-related noncommunicable diseases in the Eastern Mediterranean region. Int J Gen Med. 2012;5:199-217. https://doi.org/10.2147/IJGM.S29663 PMID:22399864

144. Chamieh MC, Moore HJ, Summerbell C, Tamim H, Sibai AM, Hwalla N. Diet, physical activity and socio-economic disparities of obesity in Lebanese adults: findings from a national study. BMC Public Health. 201503 21;15(1):279. https://doi.org/10.1186/s12889015-1605-9 PMID:25880751

145. Whitlock G, Lewington S, Sherliker P, Clarke R, Emberson J, Halsey J, et al.; Prospective Studies Collaboration. Body-mass index and cause-specific mortality in 900000 adults: collaborative analyses of 57 prospective studies. Lancet. 2009 Mar 28;373(9669):1083-96. https://doi.org/10.1016/So140-6736(o9)60318-4 PMID:19299006

146. The global burden of disease: 2004 update. Geneva: World Health Organization; 2008 (http://www.who.int/healthinfo/global_ burden_disease/GBD_report_2004update_full.pdf?ua=1, accessed 25 January 2018).

147. Global status report on noncommunicable diseases 2010. Geneva: World Health Organization; 2011 (http://www.who.int/nmh/ publications/ncd_report_full_en.pdf, accessed 25 January 2018).

148. 2008-2013 action plan for the global strategy for the prevention and control of noncommunicable diseases: prevent and control cardiovascular diseases, cancers, chronic respiratory diseases and diabetes. Geneva: World Health Organization; 2009 (http:// apps.who.int/iris/bitstream/10665/44009/1/9789241597418_eng.pdf, accessed 25 January 2018).

149. Wang Y, Lobstein T. Worldwide trends in childhood overweight and obesity. Int J Pediatr Obes. 2006;1(1):11-25. https://doi. org/10.1080/17477160600586747 PMID:17902211

150. Ahrens W, Pigeot I, Pohlabeln H, De Henauw S, Lissner L, Molnár D, et al.; IDEFICS consortium. Prevalence of overweight and obesity in European children below the age of 10. Int J Obes. 2014 Sep;38(S2) Suppl 2:S99-107. https://doi.org/10.1038/ijo.2014.140 PMID:25376223

151. Ogden CL, Carroll MD, Curtin LR, Lamb MM, Flegal KM. Prevalence of high body mass index in US children and adolescents, 2007-2008. JAMA. 2010 Jan 20;303(3):242-9. https://doi.org/10.1001/jama.2009.2012 PMID:20071470

152. Orsi CM, Hale DE, Lynch JL. Pediatric obesity epidemiology. Curr Opin Endocrinol Diabetes Obes. 2011 Feb;18(1):14-22. https://doi. org/10.1097/MED.obo13e3283423de1 PMID:21157323

153. Güngör NK. Overweight and obesity in children and adolescents. J Clin Res Pediatr Endocrinol. 2014 Sep;6(3):129-43. https://doi. org/10.4274/jcrpe.1471 PMID:25241606

154. Khader Y, Irshaidat O, Khasawneh M, Amarin Z, Alomari M, Batieha A. Overweight and obesity among school children in Jordan: prevalence and associated factors. Matern Child Health J. 2009 May;13(3):424-31. https://doi.org/10.1007/s10995-008-0362-0 PMID:18496747

155. Nasreddine L, Naja F, Hwalla, N. Early life nutrition and health in Lebanon (unpublished data). 2013.

156. Amin TT, Al-Sultan AI, Ali A. Overweight and obesity and their association with dietary habits, and sociodemographic characteristics among male primary school children in Al-Hassa, Kingdom of Saudi Arabia. Indian J Community Med. 2008 Jul;33(3):172-81. https://doi.org/10.4103/0970-0218.42058 PMID:19876479 
157. Al Junaibi A, Abdulle A, Sabri S, Hag-Ali M, Nagelkerke N. The prevalence and potential determinants of obesity among school children and adolescents in Abu Dhabi, United Arab Emirates. Int J Obes. 2013 Jan;37(1):68-74. https://doi.org/10.1038/ijo.2012.131 PMID:22890490

158. Jabre P, Sikias P, Khater-Menassa B, Baddoura R, Awada H. Overweight children in Beirut: prevalence estimates and characteristics. Child Care Health Dev. 2005 Mar;31(2):159-65. https://doi.org/10.1111/j.1365-2214.2004.00458.x PMID:15715695

159. Nasreddine L, Naja F, Akl C, Chamieh MC, Karam S, Sibai A-M, et al. Dietary, lifestyle and socio-economic correlates of overweight, obesity and central adiposity in Lebanese children and adolescents. Nutrients. 201403 10;6(3):1038-62. https://doi. org/10.3390/nu6031038 PMID:24618510

160. Al-Muhaimeed AA, Dandash K, Ismail MS, Saquib N. Prevalence and correlates of overweight status among Saudi school children. Ann Saudi Med. 2015 Jul-Aug;35(4):275-81. https://doi.org/10.5144/0256-4947.2015.275 PMID:26497706

161. Nutrient profile model for the marketing of food and non-alcoholic beverages to children in the WHO Eastern Mediterranean Region. Cairo: World Health Organization Regional Office for the Eastern Mediterranean; 2017 (http://www.who.int/iris/ handle/10665/255260, accessed 25 January 2018).

162. Nasreddine L, Naja FA, Sibai A-M, Helou K, Adra N, Hwalla N. Trends in nutritional intakes and nutrition-related cardiovascular disease risk factors in Lebanon: the need for immediate action. J Med Liban. 2014 Apr-Jun;62(2):83-91. https://doi. org/10.12816/0004102 PMID:25011369

163. Popkin BM, Adair LS, Ng SW. Global nutrition transition and the pandemic of obesity in developing countries. Nutr Rev. 2012 Jan;70(1):3-21. https://doi.org/10.1111/j.1753-4887.2011.00456.x PMID:22221213

164. Hawkes C. Uneven dietary development: linking the policies and processes of globalization with the nutrition transition, obesity and diet-related chronic diseases. Global Health. 200603 28;2(1):4. https://doi.org/10.1186/1744-8603-2-4 PMID:16569239

165. Shab-Bidar S, Hosseini-Esfahani F, Mirmiran P, Hosseinpour-Niazi S, Azizi F. Metabolic syndrome profiles, obesity measures and intake of dietary fatty acids in adults: Tehran Lipid and Glucose Study. J Hum Nutr Diet. 2014 Apr;27 Suppl 2:98-108. https://doi. org/10.1111/jhn.12117 PMID:23731333

166. Nasreddine L, Hwalla N, Saliba A, Akl C, Naja F. Prevalence and Correlates of Preschool Overweight and Obesity Amidst the Nutrition Transition: Findings from a National Cross-Sectional Study in Lebanon. Nutrients. 201703 11;9(3):266. https://doi. org/10.3390/nu9030266 PMID:28287459

167. Alissa EM, Alnahdi WA, Alama N, Ferns GA. Relationship between nutritional profile, measures of adiposity, and bone mineral density in postmenopausal Saudi women. J Am Coll Nutr. 2014;33(3):206-14. https://doi.org/10.1080/07315724.2013.866528 PMID:24869980

168. Nasreddine L, Mehio-Sibai A, Mrayati M, Adra N, Hwalla N. Adolescent obesity in Syria: prevalence and associated factors. Child Care Health Dev. 2010 May;36(3):404-13. https://doi.org/10.1111/j.1365-2214.2009.01042.x PMID:19961497

169. World Health Organization. Report on the consultation on developing strategic directions for salt and fat reduction in the Eastern Mediterranean Region, Cairo, Egypt, 28-29 November 2012. Cairo: World Health Organization Regional Office for the Eastern Mediterranean; 2013 (http://apps.who.int/iris/bitstream/10665/116172/1/IC_Meet_Rep_2013_EN_14875.pdf, accessed 25 January 2018).

170. Fats and fatty acids in human nutrition. Report of an expert consultation. Rome: Food and Agriculture Organization of the United Nations; 2010 (http://www.fao.org/docrep/013/i1953e/i1953eoo.pdf, accessed 25 January 2018).

171. Chalmers I, Bracken MB, Djulbegovic B, Garattini S, Grant J, Gülmezoglu AM, et al. How to increase value and reduce waste when research priorities are set. Lancet. 2014 Jan 11;383(9912):156-65. https://doi.org/10.1016/So140-6736(13)62229-1 PMID:24411644

172. Marketing of foods high in fat, salt and sugar to children: update 2012-2013. Copenhagen: World Health Organization Regional Office for Europe; 2013 (http://www.euro.who.int/_data/assets/pdf_file/o019/191125/eg6859.pdf?ua=1, accessed 25 January 2018).

173. Report of the commission on ending childhood obesity. Geneva: World Health Organization; 2016 (http://apps.who.int/iris/ bitstream/10665/204176/1/9789241510066_eng.pdf, accessed 25 January 2018).

174. Policy statement and recommended actions for reducing fat intake and lowering heart attack rates in the Eastern Mediterranean Region. World Health Organization (http://www.emro.who.int/nutrition/strategy/policy-statement-2013.html, accessed 25 January 2018).

175. Hanson MA, Gluckman PD. Early developmental conditioning of later health and disease: physiology or pathophysiology? Physiol Rev. 2014 Oct;94(4):1027-76. https://doi.org/10.1152/physrev.00029.2013 PMID:25287859

176. The faces of malnutrition. United Nations Children's Fund; 2016 (https://www.unicef.org/nutrition/index_faces-of-malnutrition. html, accessed 25 January 2018). 